\title{
Air Pollution and Cytokines
}

\author{
${ }^{1}$ Seema Saraswathy, ${ }^{2}$ Richa Dixit, ${ }^{3}$ Poonam Agrawal, ${ }^{4}$ Manu Krishnan
}

\begin{abstract}
Aim: The present review is aimed to assess the role of inflammatory mediators in the initiation and progression of the disorders, related to air pollution, with a special focus on cytokines.

Background: Air pollution adversely affects human health. The outdoor and indoor pollution accounts for approximately 4 million deaths every year. The major pollutants include gaseous compounds, polycyclic aromatic hydrocarbons (PAH) and particulate matter (PM). Epidemiologic data shows the increase in the incidence of cardiopulmonary and central nervous system disorders on exposure of the pollutants and how do they aggravate the pre-existing disease conditions. Also, it contributes to the higher rate in cancer prevalence also.
\end{abstract}

Review results: Numerous studies were carried out in delineating the underlying pathological changes of these diseases due to pollution. The suggestive mechanisms include the local and systemic inflammatory response and bone marrow stimulation elicited as a result of the entry of the toxic compounds. The oxidative stress developed also is said to be a contributing factor. The multiple interactions of a broad range of compounds like, cytokines, growth factors, adhesion molecules, reactive oxygen species, and acute phase proteins are also involved in the reactions.

Conclusion: Multiple interrelated molecular pathways of inflammation are stimulated as a result of air pollution and which in turn leads to the secretion of the mediators and effector molecules. Cytokines are significant intermediaries of both the innate and the adaptive immune responses. These compounds take a major position in the events in pathogenesis.

Clinical significance: The concentrations of cytokines are seen altered in circulation and tissues. Hence, these may have the potential in considering as markers for evaluating adverse effects of air pollution.

Keywords: Air pollution, Cytokines, Inflammation.

How to cite this article: Seema S, Dixit R, Agrawal P, Krishnan M. Air Pollution and Cytokines. Journal of Medical Academics 2018;1(1):43-49.

\section{Source of support: Nil}

\section{Conflict of interest: None}

\footnotetext{
${ }^{1,2}$ Tutor, ${ }^{3}$ Associate Professor, ${ }^{4}$ Classified Specialist

${ }^{1-3}$ Department of Biochemistry, Army College of Medical Sciences, Delhi Cantt, India

${ }^{4}$ Department of Dental Research and Implantology, Institute of Nuclear Medicine and Allied Sciences (INMAS), Defence Research and Development Organization (DRDO), Delhi, India

Corresponding Author: Richa Dixit, Tutor, Department of Biochemistry, Army College of Medical Sciences, Delhi Cantt, India, Phone: +919891142808, e-mail: richadixit.fmsdu@gmail. com
}

\section{BACKGROUND}

The release of pollutants from various anthropogenic sources into the atmospheric air has a severe impact on human health. World Health Organization (WHO) estimates about 3 million premature deaths by ambient (outdoor) air pollution every year, where a major fraction elicited by cardiopulmonary disorders. ${ }^{1,2}$ Similarly, indoor pollution also causes 4.3 million deaths annually. ${ }^{3}$ Air pollutants comprise of gaseous compounds like ozone $\left(\mathrm{O}_{3}\right)$, nitrogen dioxide $\left(\mathrm{NO}_{2}\right)$, carbon monoxide $(\mathrm{CO})$, sulfur dioxide $\left(\mathrm{SO}_{2}\right)$, lead $(\mathrm{Pb})$ and particulate matter of less than 10 and 2.5microns $\left(\mathrm{PM}_{10}\right.$ and $\left.\mathrm{PM}_{2.5}\right)$. PM consists of particles of sulfate, nitrates, ammonia, sodium chloride, black carbon, mineral dust, and water. The open burning in agricultural fields, coal mining, transport, and power generation emit PM and some other gaseous pollutants. ${ }^{1-3}$ Further, combustion of fossil fuel and agricultural waste generates organic matters like polycyclic aromatic hydrocarbons (PAH), benzene, formaldehyde and some toxic molecules including fluorine, arsenic, selenium, and mercury. ${ }^{3}$

Recent past has witnessed a surge in research on the harmful effects of these compounds on human health. The particulate matters less than 10 microns are deposited on the bronchial pathways whereas the ultrafine particles infiltrate and enter to circulation reaching various organ systems. Pulmonary function is severely affected, which leads to the increase in the incidence of infections, asthma and chronic obstructive pulmonary disease (COPD). ${ }^{4,5}$ Another detrimental effect of these pollutants is that they cross the blood-brain barrier and cause inflammatory changes in the central nervous system. This enhances the risk of developmental disorders, Parkinson's disease as well as stroke. ${ }^{6}$ The exposure of particulate matter is harmful to the cardiovascular system too; it causes acute coronary syndrome and heart failure. More so, continuous exposure may lead to the development of type 2 diabetes mellitus, and hypertension. ${ }^{7}$ Children and the elderly are the most vulnerable population. ${ }^{8,9}$

In addition to the cardiopulmonary complications, outdoor air pollution can initiate carcinogenesis also. The international agency for research on cancer (IARC) classified PM as the cause of lung cancer. ${ }^{10}$ Epidemiological data confirm the various health issues starting from allergic symptoms to reproductive and developmental complications. Besides, it disrupts the endocrine activities 
as well. ${ }^{11}$ Recent updates demonstrate the impairment of cognitive processes and the defective gametogenesis with long-term contact. ${ }^{12,13}$ A positive correlation of dental caries and exposure to the environmental pollutants has also been cited. ${ }^{14}$ The chemicals, in fact, impair the homeostasis of the body. Table 1 describes the various air pollutants and their health impacts.

Several studies are underway to decipher the underlying mechanism by which the pollutants make worse the cellular/tissue function. Cytokines and inflammatory molecules have been observed to play a key role in this. Cytokines are a group of low molecular weight proteins secreted by the immune system cells. Their release activates a cascade of reactions leading to the systemic inflammation and consequent events. ${ }^{15}$ Interleukins, tumor necrosis factor (TNF), interferons, Granulocyte-

Table 1: Common air pollutants and their health impact

\begin{tabular}{|c|c|c|c|c|}
\hline $\begin{array}{l}\text { Air } \\
\text { pollutants }\end{array}$ & $\begin{array}{l}\text { Time } \\
\text { period }\end{array}$ & $\begin{array}{l}\text { Air quality } \\
\text { standard* }^{*}\end{array}$ & Source & Health effects \\
\hline Ozone & $8 \mathrm{hr}$ & $100 \mu \mathrm{g} / \mathrm{m}^{3}$ & $\begin{array}{l}\text { Industries, } \\
\text { electric } \\
\text { utilities, } \\
\text { motor } \\
\text { vehicles }\end{array}$ & $\begin{array}{l}\text { Respiratory } \\
\text { illness and } \\
\text { asthma }\end{array}$ \\
\hline PM 2.5 & $24 \mathrm{hr}$ & $25 \mu \mathrm{g} / \mathrm{m}^{3}$ & $\begin{array}{l}\text { Industries, } \\
\text { motor } \\
\text { vehicles }\end{array}$ & $\begin{array}{l}\text { Respiratory and } \\
\text { cardiovascular } \\
\text { diseases }\end{array}$ \\
\hline PM10 & $24 \mathrm{hr}$ & $50 \mu \mathrm{g} / \mathrm{m}^{3}$ & $\begin{array}{l}\text { Industries, } \\
\text { motor } \\
\text { vehicles, } \\
\text { construction/ } \\
\text { demolition } \\
\text { operations, } \\
\text { burning }\end{array}$ & $\begin{array}{l}\text { Respiratory and } \\
\text { cardiovascular } \\
\text { diseases }\end{array}$ \\
\hline $\begin{array}{l}\text { Sulphur } \\
\text { dioxide }\end{array}$ & $24 \mathrm{~h}$ & $20 \mu \mathrm{g} / \mathrm{m}^{3}$ & $\begin{array}{l}\text { Fossil fuel } \\
\text { combustion, } \\
\text { industry }\end{array}$ & $\begin{array}{l}\text { Chronic } \\
\text { respiratory } \\
\text { diseases and } \\
\text { allergy }\end{array}$ \\
\hline $\begin{array}{l}\text { Nitrogen } \\
\text { dioxide }\end{array}$ & $1 \mathrm{yr}$ & $40 \mu \mathrm{g} / \mathrm{m}^{3}$ & $\begin{array}{l}\text { Vehicular } \\
\text { exhaust }\end{array}$ & $\begin{array}{l}\text { Respiratory } \\
\text { diseases and } \\
\text { allergy }\end{array}$ \\
\hline $\begin{array}{l}\text { Carbon } \\
\text { monoxide }\end{array}$ & $8 \mathrm{hr}$ & $9 p p m$ & $\begin{array}{l}\text { Vehicular } \\
\text { exhaust, } \\
\text { burning of } \\
\text { coal \&wood, } \\
\text { Industries }\end{array}$ & $\begin{array}{l}\text { Cardiovascular } \\
\text { disorders and } \\
\text { allergy }\end{array}$ \\
\hline Lead & 3months & $1.5 \mu \mathrm{g} / \mathrm{m}^{3}$ & $\begin{array}{l}\text { Combustion } \\
\text { of leaded } \\
\text { gasoline } \\
\text { in motor } \\
\text { vehicles }\end{array}$ & $\begin{array}{l}\text { Lead } \\
\text { accumulates } \\
\text { in bones, } \\
\text { blood, and soft } \\
\text { tissues, Neuro } \\
\text { developmental } \\
\text { effects }\end{array}$ \\
\hline PAH & $1 \mathrm{yr}$ & $1 \mathrm{ng} / \mathrm{m}^{3}$ & $\begin{array}{l}\text { Fuel } \\
\text { combustion, } \\
\text { burning of } \\
\text { coal \& wood }\end{array}$ & $\begin{array}{l}\text { Respiratory, } \\
\text { Nervous system } \\
\text { disorders and } \\
\text { cancer }\end{array}$ \\
\hline
\end{tabular}

PM: Particulate matter, PAH: Polycyclic aromatic hydrocarbons

*As per the WHO air quality guidelines 2006 and United States Environmental Protection Agency macrophage colony-stimulating factors [vascular endothelial growth factor (VEGF), epidermal growth factor (EGF)], are some of the cytokines altered in eliciting the response. Many other growth factors (VEGF, EGF), adhesion molecules [vascular adhesion molecule (VCAM)], intercellular adhesion molecule (ICAM), acute phase proteins [C-reactive protein (CRP)], other inflammatory molecules (plasminogen activator inhibitor-1, myeloperoxidase, monocyte chemoattractant protein-1 (MCP-1) are also getting stimulated by these compounds. ${ }^{16}$ So, a series of interrelated molecular pathways are associated with the development of these diseases. The overall profile of alteration of cytokines with air pollution has been given in Table 2. Presence of these compounds in various body fluids and tissues has been detected. In another perspective, the cytokines in plasma/serum or saliva can be considered as a parameter for assessment of the incidence or severity of the disease. However, a focused analysis of cytokines to organ-specific pathology has not been well explored. Hence, this review evaluates the involvement of cytokines in various health issues related to air pollution and also focuses to assess their translational use as biomarkers for screening and disease progression.

\section{Role of Cytokines in Various Diseases due to Air Pollution}

Cytokines are small molecules secreted predominantly by $\mathrm{T}$ helper cells (Th) and macrophages. They regulate the immune and inflammatory response and are also involved in hematopoiesis. These molecules are pleiotropic and can signal in autocrine, paracrine and endocrine manner. Their receptor-mediated actions contribute to many disease pathologies. ${ }^{17}$ Different classes of these molecules are defined based on their functions. These include, pro-inflammatory (IL-1, IL-6, TNF- $\alpha$, IL-8), antiinflammatory (IL-10, TGF- $\beta$ ), anti-infectious (IFN $\alpha$, IFN $\beta$, IFN $\gamma, \mathrm{TNF} \alpha$ ), activating B cells (IL-3, IL-4, IL-5, IL-6, IL-21), activating T cells (IL-2,IL-4, IL-10, IL-13, IL-15), mast cell activating (IL-3, IL-4, IL-13, IL-5) and hematopoietic (GMCSF, IL-3, G-CSF, M-CSF, IL-5, IL-7) . ${ }^{18}$ Because cytokines are involved the pathogenesis of the disease, it may be considered as potential molecules for diagnosis/prognosis as well as for therapeutic purposes.

The imbalance of pro and anti-inflammatory molecules have been detected in human serum who are on continuous exposure to air pollutants. ${ }^{15}$ Ozone exposure has been cited to cause an increase in the submucosal mast cells which is a source for pro-inflammatory cytokines. Up/down-regulation of interleukins and inflammatory mediators has been correlated with various cardiac, respiratory and central nervous system (CNS) diseases. ${ }^{19,20}$ In confirmation, the reports on animal experiments/ cell culture too explain the inflammatory changes when exposed to the toxic pollutants as well. Recently, the activation of mitogen-activated protein kinase (MAPK) and 


\begin{tabular}{|c|c|c|c|c|c|}
\hline Pollutants & Specimen & Cytokines increased & Cytokines decreased & Health effects & Ref. \\
\hline $\begin{array}{l}\text { Ambient urban particles } \\
\text { (EHC 93), inert carbon } \\
\text { particles and latex } \\
\text { particles }\end{array}$ & $\begin{array}{l}\text { Human alveolar } \\
\text { macrophages (AM) } \\
\text { (In vitro) }\end{array}$ & $\begin{array}{l}\text { TNF- } \alpha, \\
\text { IL-6, IL-1 } \beta \text {, } \\
\text { GM-CSF }\end{array}$ & IL-10 & Respiratory diseases & 26 \\
\hline PM10 & Serum & IL-1 $\beta$, IL-6, GM-CSF & - & Respiratory diseases & 26 \\
\hline $\mathrm{O} 3, \mathrm{NO} 2, \mathrm{CO}, \mathrm{SO} 2$ & Saliva (Children) & IL-8 & & Oral diseases & 38 \\
\hline PM2.5 & Plasma & $\mathrm{IL}-10$ & TNF- $\alpha$ & $\begin{array}{l}\text { Allergy and } \\
\text { autoimmune }\end{array}$ & 15 \\
\hline PM2.5 & Plasma & TNF $\alpha$, IL-6, IL-1 $\beta$ & & $\begin{array}{l}\text { Atherogenesis, acute } \\
\text { coronary syndrome }\end{array}$ & 30 \\
\hline Polluted air & Plasma & - & IL-6 & Atherosclerotic diseases & 31 \\
\hline $\begin{array}{l}\text { Long term exposure of } \\
\text { NO2 }\end{array}$ & Peripheral blood & - & $\begin{array}{l}\text { IL-2, IL-10, IL- } \\
\text { 8,TNF- } \alpha\end{array}$ & $\begin{array}{l}\text { Cancer, respiratory and } \\
\text { cardiovascular diseases }\end{array}$ & 37 \\
\hline PM2.5 & Tears & - & IL-5, IL-10 & Ocular hazards & - \\
\hline $\begin{array}{l}\text { PM2.5, volatile organic } \\
\text { compounds }\end{array}$ & Blood & & $\begin{array}{l}\text { IL-6, IL-5, 1L-13, } \\
\text { IFNy, TNF- } \alpha\end{array}$ & $\begin{array}{l}\text { Respiratory diseases and } \\
\text { COPD }\end{array}$ & 27 \\
\hline PM2.5 & $\begin{array}{l}\text { Rat Hippo-campal } \\
\text { tissue }\end{array}$ & $\begin{array}{l}\text { TNF- } \alpha \text {, } \\
\text { IL-1 } \beta \text { (Gene expression) }\end{array}$ & - & Neurological disorders & 12 \\
\hline PM10 & Peripheral blood & $\|-4, I L-13$ & & Allergic diseases & - \\
\hline
\end{tabular}

IL: Interleukins, TNF-a: Tumor necrosis factor- $\alpha$, IFNy: Interferon y, GM-CSF: Granulocyte-macrophage-colony-stimulating factor, COPD: Chronic obstructive pulmonary disorder

NF-kB pathways was also observed as a result of inhalation of toxic pollutants. ${ }^{21}$ The effect of air pollution on various organ systems and the related molecular events are illustrated in Figure 1. Estimate of the specific effect of these pollutants in various organ systems may be helpful in identifying markers for air pollution.

\section{Respiratory Disorders}

Air pollution mainly affects the respiratory system. It has direct influence because of the large area of contact between atmosphere and surface of the airway. ${ }^{22}$ Acute exposure increases the frequency of respiratory infections, pneumonia, and allergy. It also contributes to respiratory mortality. The diseased conditions of asthma/ COPD get aggravated by inhaling these pollutants. The prevalence of COPD and lung cancer has been raised by long-term exposure. Chronic changes in pulmonary functions also have been cited. ${ }^{22,23}$

The proposed mechanisms involve the deposition of pollutants in the lung alveoli and initiation of the inflam-

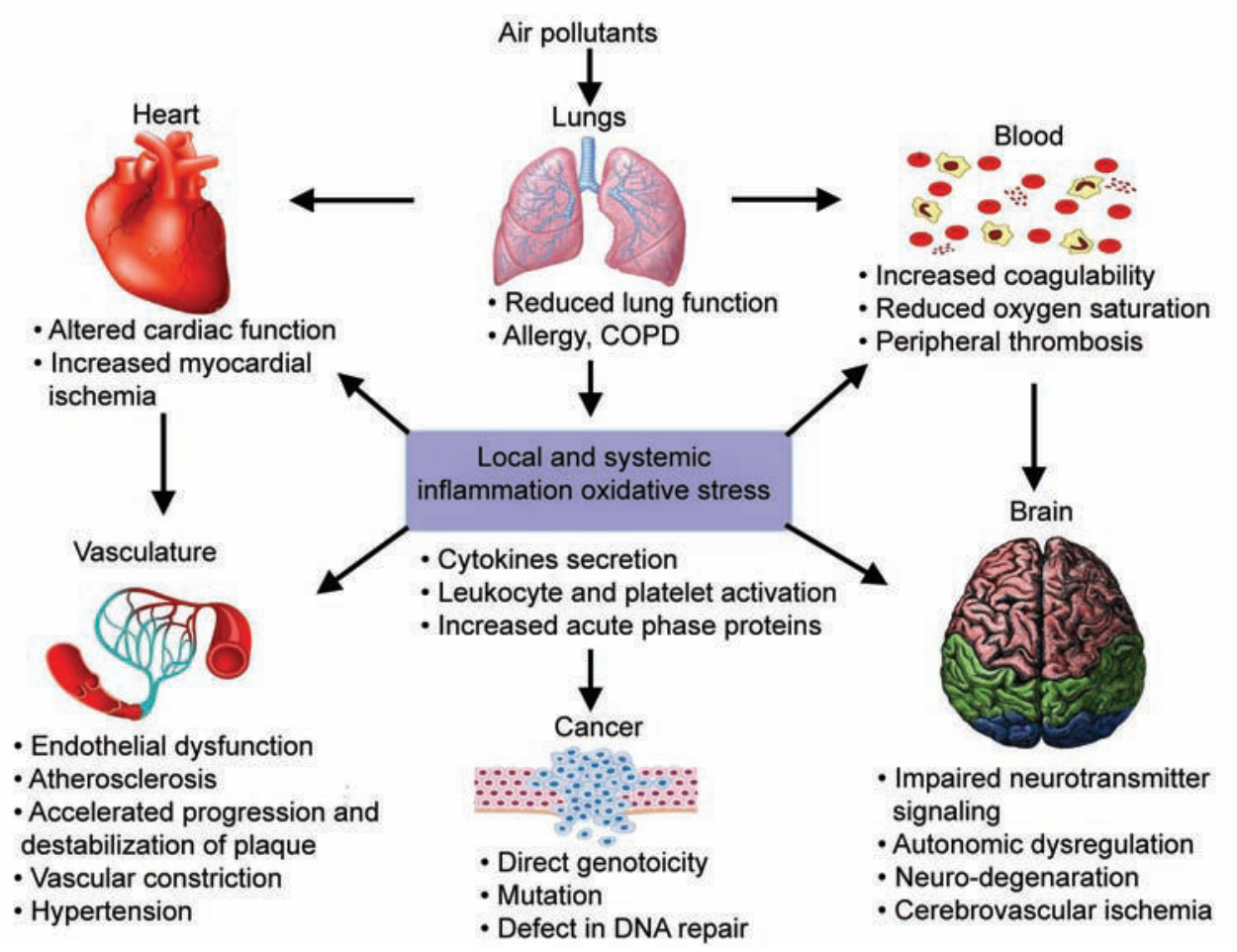

Fig. 1: The effect of air pollution on various organ systems and the related molecular events 
matory response. Alveolar macrophages are primarily involved in the local and systemic inflammation. The phagocytic activity of these cells is increased as result of particle inhalation and this induces the release of mediators of inflammation like tumor necrosis factor-alpha $(\mathrm{TNF}-\alpha)$ and interleukins. Hematopoietic system is activated, and leukocytes are increased in circulation. ${ }^{24}$ These events augment the immune responses. In addition to the pulmonary inflammation, reactive oxygen species (ROS) are generated by phagocytes and epithelial cells during contact with the airborne particles; as a consequence, oxidative stress is developed. ${ }^{25}$ All these molecular events contribute to the pathologic changes.

Many investigations documented the alterations in the mediators of inflammation subsequent to air pollution. The changes in cytokine levels were observed in an in-vitro study conducted with the incubation of different pollutants with human alveolar macrophages. TNF- $\alpha$ was found to be increased with all pollutants with a simultaneous increase in the IL-6, IL-1, macrophage inflammatory protein-1 (MIP-1) and GM-CSF. However, there was no change in levels of IL-10, the anti-inflammatory marker. ${ }^{26}$ The pro-inflammatory cytokines in serum of patients were increased in acute exposure cases of $\mathrm{PM}_{10}$. In another comparative study evaluating the cytokine levels in persons living in polluted vs. less polluted cities demonstrated an increase of IL-10. ${ }^{15}$ However, the inverse correlation of the circulating cytokines and the respiratory diseases were also noticed in a study in which the individuals are exposed to PM2.5 (outdoor) and volatile organic compounds (indoor). A decrease in IL-6, IL-5, and $1 \mathrm{~L}-13$ was seen in cases with respiratory illness and COPD. The inverse correlations were explained by the suppression of immune response as a part of adaptive mechanisms. ${ }^{27}$ The modifications of cytokines occur as a result of exposure to air pollutants, and probably, they take a critical role in the pathogenesis.

\section{Cardiovascular Diseases}

Air pollution increases the risk of coronary heart disease (CHD), cardiac arrhythmia, thrombosis, and atherosclerosis. ${ }^{28}$ Cardiovascular difficulties due to the air pollutants are mainly because of the systemic inflammation and endothelial injury. The direct and indirect mechanisms play roles in the development of vascular diseases by air pollutants. Directly, the fine particles reach the alveoli enters into circulation and deposit on the vascular endothelium which can stimulate oxidative stress and destabilizes the atherosclerotic plaque. This will cause thrombus formation..$^{28}$ The indirect effects are due to the cytokine-mediated inflammation. Further, it alters blood coagulability and imbalances the vasoactive molecules. This supports the dysfunction of endothelium, vasoconstriction, and development of oxidative stress which leads to atherosclerosis and hypertension. ${ }^{7}$ Likewise, ultrafine particles promote atherosclerosis/ calcification of arteries and activate platelets. This may result in arterial thrombosis. ${ }^{29}$

The group of cytokines were quantified in plasma of $\mathrm{PM}_{2.5}$ exposed subjects and reported an increase in anti-angiogenic (TNF $\alpha$, IP-10 (interferon $\gamma$-induced protein 10)) and proinflammatory cytokines (IL-6, IL-1 $\beta$ ). The reduction in pro-angiogenic growth factors (EGF (epidermal growth factor), VEGF (vascular endothelial growth factor)) was also noted. Also, markers of endothelial adhesion sICAM-1and sVCAM-1were also involved. These might be secreted by the stimulation of cytokines. ${ }^{30}$ Another study concludes that changes are limited only to a susceptible population. Accordingly, CRP, Myeloperoxidase showed an increase where plasminogen activator inhibitor-1 (PAI-1) and IL-6 were on the decline. ${ }^{31}$ It is understood that cytokines and the downstream effectors have definitive functions in the progression of cardiovascular diseases.

\section{Neurological diseases}

Central nervous system (CNS) is another target organ for air pollution effects. Chronic exposure results in an ischemic stroke. Further, Alzheimer's disease (AD), Parkinson's disease (PD), are strongly linked to air pollution. $\mathrm{PM}$, or nanosized particles, either enter directly through olfactory mucosa or the cytokines released as a part of systemic inflammation reaches the brain. It activates cerebral endothelial cells and disturbs the blood-brain barrier. ${ }^{32}$ The nervous system is affected by the ROS generation and activation of pro-inflammatory pathways during exposure to pollutants. The stimulation of neurokinin A, a neuropeptide, by sensory neurons in contact with particles too contributes for neurogenic inflammation. Hence, The inflammatory reactions are mediated by cytokines, chemokines and oxidative stress. ${ }^{33}$ Also, irritant particle deposition can cause depression. At the molecular level, depression is related with the dopamine reduction in the central nervous system. Fonken et al. reported the induction of dopaminergic neurotoxicity by air pollutants related oxidative stress. ${ }^{33}$

Long-term exposure can lead to impairment in neurotransmitter signaling, neuronal remodeling and finally neurodegeneration and impaired cognition. The hippocampus is mostly affected, and it aggravates Alzheimer's disease. An animal study reported the depressive response and impairment in learning and memory for mice exposed to $\mathrm{PM}_{2.5}$ for 10 months. ${ }^{12}$ In another in-vivo study carried out by exposing mice to 
carbon black and injected with lipoteichoic acid (LTA). The messenger RNA (mRNA) expression of IL-1 $\beta$ with the alteration of neurotransmitters was seen in mouse olfactory mucosa with LTA. ${ }^{34}$ Here, it can be noted that continuous activation of immune processes is negatively impairing the normal cellular functions.

\section{Cancer}

The association of carcinogenesis and air pollution has been explored well. A long-term follow-up study consists of 66,280 participants performed in Hong Kong reported the increase of mortality of about 42 percent in carcinoma of digestive system due to $10 \mathrm{\mu g} / \mathrm{m}^{3}$ increase of $\mathrm{PM}_{2.5}$. In the case of breast and lung cancer, it was $80 \%$ and $36 \%$ respectively. Majority of the lung cancer deaths are results of air pollution. Exposure to $\mathrm{NO}_{2}$ also has been identified as a risk factor for lung cancer. The long-term contact increases the danger of bladder cancer/brain cancer too. ${ }^{35}$

The probable changes occur in cells which initiate carcinogenesis include; defects in deoxyribonucleic acid (DNA) repair function, alterations in the body's immune response and activate angiogenesis. Chronic inflammation and ROS generation favors cellular malignant transformation of cells. Integrins, the cytoskeleton protein, interacts with the DNA regulating pathways and stimulate the extracellular matrix (ECM) degrading proteins, connective tissue growth factor (CTFG), transforming growth factor beta (TGF-beta), and interleukins. ${ }^{36}$

Heavy metal poisoning has an effect on the bacteria of the intestine and promotes cancerous changes. The genotoxicity of outdoor air pollutants has been confirmed from the single-stranded DNA breaks on exposure to diesel exhaust particles, smoke/dust. The mice exposed to ambient air for 10 weeks showed a high level of expanded simple tandem repeated mutation (ESTAR) in spermatogonial stem cells. In a cohort study, a strong association has been noticed with the incidence of a brain tumor and $\mathrm{PM}_{2.5} \cdot{ }^{10}$ The pollutants directly are genotoxic to the cells, or it can act indirectly causing DNA aberrations through eliciting inflammatory changes.

\section{Cytokines as Markers of Air Pollution}

Here, mechanisms related to biological effects of pollutants demonstrated the key involvement of inflammatory pathways. This includes the changes in the levels of cytokines and other inflammatory molecules. The rise in promoters of inflammations such as TNF- $\alpha$ has been noticed in all diseases except for the allergic/autoimmune disorders. The Increase in levels of pro-inflammatory/B cell-activating cytokine, IL-6, has been associated with respiratory disturbances where the reverse is seen with other inflammatory cytokines (IL-5, IL-8, and IL-17) with COPD on long-term exposure to $\mathrm{PM}_{2.5}$ and volatile organic compounds. Similarly, reducing levels of IL-2, IL-8, IL-10, and TNF $\alpha$ was associated with long-term inhalation of oxides of nitrogen. ${ }^{37}$ However; increase of salivary IL-8 was seen in children exposed to $\mathrm{PM}_{2.5} \cdot{ }^{38} \mathrm{In}$ the same way, neurological symptoms correlated with high level of IL-1 $\beta$. All these data indicate that the concentrations of cytokine molecules in body fluids depend on the type and time of exposure of pollutants.

\section{Methods of Detection of Cytokines}

Different methods are used for quantifying cytokines. The secreted cytokines usually are detected by enzyme linked immuno sorbent assay (ELISA) using specific antibodies. This method is simple, accurate and cost-effective. However, a smaller amount of tissue fluids collected and the threshold of detection of ELISA limit the accuracy of results. The advanced technology of cytokine bead assay is beneficial in detecting a panel of cytokines in a multiplex manner with very small sample volumes. This test is of high cost, low sensitivity and underestimation due to fewer amounts of cytokines released due to cellular consumption. The cytokines are detected at the stage of gene expression by mRNA quantification by polymerase chain reaction (PCR). This requires only very small volumes and can be done at tissue/cellular level. This is a highly sensitive method. But due to the post-translational modifications (IL-1 and IL-8), it may not replicate the actual protein levels. So, the results vary with the percentage of cytokine releasing cells in tissue as well. ${ }^{39}$

The cytokine-producing cells are detected by immunohistochemistry. This method is sensitive enough to detect less number of cytokine-producing cells in the tissue. The main disadvantage of this method is that it is not quantitative and cannot detect secreted molecules. In situ hybridization technique can be used in tissue mRNA detection. This uses fluorescent/radiolabeled complementary strands of DNA/RNA for identification. ${ }^{39}$ The proteomic analysis by mass spectrometric techniques is also a promising approach for discovering the specific cytokines involved in pathogenesis. ${ }^{40}$ The identification of markers will aid in delineating the molecular pathways involved in pathogenesis.

\section{CONCLUSION}

In this review, we attempted to analyze the different mechanisms underlying the initiation/progression of the diseases caused by air pollution. It has been observed that continuous activation of the immune system occurs subsequent to the exposure to pollutants. This would stimulate many interrelated molecular pathways of inflammation and which in turn results in secretion of the 
mediators and effector molecules like cytokines, growth factors, adhesion molecules, etc. Cytokines take a major position in the events in pathogenesis. Hence, these can be considered for evaluating the severity of air pollution. In addition, epidemiological and molecular studies may assist in taking steps to reduce the risk of air pollution.

\section{CLINICAL SIGNIFICANCE}

Cytokines are significant intermediaries of both the innate and the adaptive immune responses. They are primarily involved in the events of pathogenesis in air pollution-related diseases. Hence, these may have the potential in considering as markers for evaluating adverse effects of air pollution.

\section{REFERENCES}

1. World Health Organization. Ambient air pollution: health impacts [Internet]. Geneva: World Health Organization; May 2018. Available from http://www.who.int/airpollution/ ambient/health-impacts/en/.

2. World Health Organization. Air pollution [Internet]. Geneva: World Health Organization; May 2018. Available from http:// www.who.int/airpollution/data/en/.

3. TERI. Air Pollution and Health. Discussion Paper by the Energy and Resources Institute. New Delhi: TERI; 2015. Available from http://www.teriin.org/projects/teddy/pdf/ air-pollution-health-discussion-paper.pdf.

4. Jiang XQ, Mei XD, Feng D. Air pollution and chronic air way diseases:what should people know and do? J Thorac Dis. 2016 Jan;8(1): e31-40.

5. Kelly FJ, Fussell JC. Air pollution and airway disease. Clin Exp Allergy. 2011 Aug; 41(8): 1059-1071.

6. Brockmeyer S, D'Angiulli A. How air pollution alters brain development: the role of neuroinflammation. Transl Neurosci. 2016 Mar; 7(1):24-30.

7. Hadley MB, Vedanthan R, Fuster V. Air pollution and cardiovascular disease: a window of opportunity. Nat Rev Cardiol. 2018 Apr; 15(4). 193-194.

8. Rees N. Danger in the air: How air pollution can affect brain development in young children. New York: United Nations Children's Fund (UNICEF); 2017. Available from https://www. unicef.org/environment/files/Danger in the Air.pdf.

9. Simoni M, Baldacci S, Maio S, Cerrai S, Sarno G, Viegi G. Adverse effects of outdoor pollution in the elderly. J Thorac Dis. 2015 Jan;7(1):34-45.

10. Straif K, Cohen A, Samet J. Air Pollution and Cancer. France: International Agency for Research on Cancer; 2013. pp 123-149.

11. Bolden AL, Schultz K, Pelch KE, Kwiatkowski CF. Exploring the endocrine activity of air pollutants associated with unconventional oil and gas extraction. Environ Health. 2018 Mar;17(1):26-33.

12. Fonken LK, Xu X, Weil ZM, Chen G, Sun Q, Rajagopalan S, et al. Air pollution impairs cognition, provokes depressive like behaviours and alters hippocampal cytokine expression and morphology. Mol Psychiatry. 2011 Oct;16(10):987-995.

13. Carre J, Gatimel N, Moreau J, Parinaud J, Leandri R. Does air pollution play role in infertility?: a systematic review. Environ Health. 2017 Jul;16(1):82.
14. Praveen K. Investigating Possible. Effects of Environmental Pollution on Dental Caries Prevalence. Masters thesis, Indian Institute of Science Education and Research Kolkata. 2014.

15. Dobreva ZG, Kostadinova GS, Popov BN, Petkov GS, Stanilova SA. Pro-inflammatory and anti-inflammatory cytokines in adolescents from south east Bulgarian cities with different levels of air pollution. Toxicol Ind Health. Dec;31(12):1210-1217.

16. Becker S, Mundandhara S, Devlin RB, Madden M. Regulation of cytokine production in human alveolar macrophages and airway epithelial cells in response to ambient air pollution particles: further mechanistic studies. Toxicol Appl Pharmacol. 2005 Sept;207(2 Suppl):S269-S275.

17. Zhang JM, An J. Cytokines, inflammation, and pain. Int Anesthesiol Clin. 2007 Spring;45(2):27-37.

18. Kindt T, Goldsby R, Osborne B, Kuby J. Kuby immunology. $6^{\text {th }}$ ed. New York: W.H. Freeman; 2007.

19. Hackett T-L, Holloway R, Holgate ST, Warner JA. Dynamics of pro-inflammatory and anti-inflammatory cytokine release during acute inflammation in chronic obstructive pulmonary disease: an ex vivo study. Respir Res. 2008 May;9:47.

20. Ljungman P, Bellander T, Schneider A, Breitner S, Forastiere F, Hampel R, et al. Modification of the interleukin- 6 response to air pollution by interleukin- 6 and fibrinogen polymorphisms . Environ Health Perspect. 2009 Sept;117(9):1373.

21. Liu YW, Chen CC, Tseng HP, Chang WC. Lipopolysaccharide-induced transcriptional activation of interleukin-10 is mediated by MAPK- and NF-kBinduced CCAAT/enhancerbinding protein delta in mouse macrophages. Cell Signal. 2006 Sep;18(9):1492-1500.

22. Arbex MA, Santos UP, Martins LC, Saldiva PHN, Pereira LAA, Braga ALF. Air pollution and respiratory system. J Bras Pneumol. 2012 Aug; 38(5):643-655.

23. Downs SH, Schindler C, Liu LJ, Keidel D, Bayer-Oglesby L, Brutsche MH, et al. Reduced exposure to PM10 and attenuated age-related decline in lung function. N Engl J Med. 2007 Dec; 357(23):2338-2347.

24. Godleski JJ, Clarke RW, Coull BA. Composition of inhaled urban air particles determines acute pulmonary responses. Ann Occup Hyg. 2002;46(Suppl 1):419-424.

25. Becker S, Soukup JM, Gilmour MI, Devlin RB. Stimulation of human and rat alveolar macrophages by urban air particulates: effects on oxidant radical generation and cytokine production. Toxicol Appl Pharmacol 1996;141:637-648.

26. Van Eeden SF, Tan WC, Suwa T, Mukae H, Terashima T, Fujii $\mathrm{T}$, et al. Cytokines involved in the systemic inflammatory response induced by exposure to particulate matter air pollutants (PM10). Am J Respir Crit Care Med. 2001 Sep;164(5):826830.

27. Audi C, Baiz N, Maesano CN, Ramousse O, Reboulleau D, Magnan A, et al. Serum cytokine levels related to exposure to volatile organic compounds and $\mathrm{PM}_{2.5}$ in dwelling and workplaces in French farmers-a mechanism to explain non-smoking COPD. Int J Chron Obstruct Pulmon Dis. 2017 May;12:1363-1374.

28. Du Y, Xu X, Chu M, Guo Y, Wang J. Air particulate matter and cardiovascular disease: the epidemiological, biomedical and clinical evidence. J Thorac Dis. 2016 Jan;8(1):e8-19.

29. Poursafa P, Kelishadi R. Air pollution, platelet activation and atherosclerosis. Inflamm Allergy Drug Targets. 2010 Dec; 9(5): 387-392.

30. Pope CA, Bhatnagar A, McCracken JP, Abplanalp W, Conklin DJ, O;Toole T. Exposure to fine particulate air pollution is 
associated with endothelial injury and systemic inflammation. Circ Res. Nov;119(11):1204-1214.

31. Ruckerl R, Hampel R, Breitner S, Cyrys J, Kraus U, Carter J, et al. Associations between ambient air pollution and blood markers of inflammation and coagulation/fibrinolysis in susceptible populations. Environ Int. 2014 Sep;70:32-49.

32. Genc S, Zadeoglulari Z, Fuss SH, Genc K. The adverse effects of air pollution on the nervous system. Journal of Toxicology. 2012;2012:1-23

33. Block ML, Calderon-Garciduenas L. Air pollution: mechanisms of neuroinflammation and CNS disease. Trends Neurosci. 2009 Sep;32(9):506-516.

34. Zanchi AC, Venturini CD, Saiki M, Nascimento Saldiva PH, Tannhauser Barros HM, Rhoden C R. “Chronic nasal instillation of residual-oil fly ash (ROFA) induces brain lipid peroxidation and behavioral changes in rats," Inhalation Toxicology. 2008;20(9): pp. 795-800.

35. University of Birmingham. Exposure to particulate air pollutants associated with numerous cancers [Internet]. Hong Kong.
University of Birmingham; Apr 2016. Available from https:// www.sciencedaily.com/releases/2016/04/160429095025.htm.

36. ManzettiS, Anderson O. Biochemical and physiological effects from exhaust emissions. A review of literature. Pathophysiology. 2016 Dec;23(4):285-293.

37. Mostafavi N, Vlaanderen J, Chadeau-Hyam M. Beelen R, Modig L, Palli D. Inflammatory markers in relation to long term air pollution.Environ Int. 2015 Aug;81:1-7.

38. Mehrbani SP, Babaloo Z, Jamali Z, Abdollahian T, Eslami $\mathrm{H}$, Sobhani N. Effect of air pollution on salivary interleukin-8 levels in Children. World Journal of Dentistry, 2016 Oct;7(4):175-178.

39. Amsen D, de Visser KE, Town T. Approaches to determine expression of inflammatory cytokines. Methods Mol Biol. 2009;511:107-142.

40. Kupcova Skalnikova H, Cizkova J, Cervenka J, Vodicka P. Advances in proteomic techniques for cytokine analysis: Focus on melanoma research. Int J Mol Sci. 2017 Dec;18(12): e2697. 